\title{
The Spatial and Temporal Distribution Characteristics of Rainstorm Disaster in Sichuan Province over the Past Decade
}

\author{
Jie Gao',2, Jianhua Pan1, Mingtian Wang1, Shanyun Guo ${ }^{1}$ \\ ${ }^{1}$ Sichuan Provincial Meteorological Observatory, Chengdu, China \\ ${ }^{2}$ Heavy Rain and Drought-Flood Disasters in Plateau and Basin Key Laboratory of Sichuan Province, Chengdu, China \\ Email:xueyinfenfei@qq.com
}

How to cite this paper: Gao, J., Pan, J.H., Wang, M.T. and Guo, S.Y. (2017) The Spatial and Temporal Distribution Characteristics of Rainstorm Disaster in Sichuan Province over the Past Decade. Journal of Geoscience and Environment Protection, 5, 1-9.

https://doi.org/10.4236/gep.2017.58001

Received: March 29, 2017

Accepted: July 16, 2017

Published: July 19, 2017

Copyright $\odot 2017$ by authors and Scientific Research Publishing Inc. This work is licensed under the Creative Commons Attribution International License (CC BY 4.0).

http://creativecommons.org/licenses/by/4.0/

(c) $\underset{\mathrm{EY}}{(7)}$ Open Access

\begin{abstract}
The spatial and temporal distribution characteristics of rainstorm disaster in Sichuan Province were investigated by statistical analysis method based on 2002-2015 rainstorm disaster data of Sichuan Province. As shown by the results, the rainstorm disaster in Sichuan Province was distributed mainly in four regions including Liangshan Prefecture and Sichuan Basin during 2002-2015, and the rainstorm disaster distribution had a good corresponding relationship with the rainstorm center regions; in terms of annual variation trend, the variation of rainstorm disaster frequency showed a significant quasi-2-3-year oscillation period; in terms of monthly distribution, June, July and August saw the heaviest rainstorms; the high death toll from rainstorms was attributed to not only routine rainfall, occurrence time and terrain feature, but also the populace's awareness of disaster prevention and the disaster prevention measures they adopted. The research result has important significance to improve the pertinence and practicability of decision-making meteorological services.
\end{abstract}

\section{Keywords}

Spatial and Temporal Distribution, Rainstorm Disaster, Sichuan

\section{Introduction}

Because of the significant difference in terrain between the eastern and western regions, rainstorm distribution in Sichuan Province has remarkable regional characteristics. The basin area is the rainstorm region consisting primarily of three rainstorm center regions, namely Qingyi River Rainstorm Region, Long- 
men Mountain Rainstorm Region, and Daba Mountain Rainstorm Region [1]. Rainstorm is a severe disaster that affects severe weather. A region of heavy rain or rainstorm, often lead to flash floods, reservoir collapse dam, river overflowing, houses being flushed, farmland being submerged, traffic and telecommunications interruption, will give the national economy and people's lives and property serious harm. Heavy rain, especially large-scale persistent heavy rain and concentrated heavy rain, not only affects the industrial and agricultural production, and may endanger the lives of the people, causing serious economic losses.

Previous studies on rainstorm disaster in Sichuan Province focus mainly on discussing the spatial-temporal distribution of rainstorm, while there are very few studies on the spatial and temporal distribution characteristics of rainstorm disaster conditions. Besides, in routine decision-making service work, we often feel that we have insufficient knowledge of the frequency, intensity and impact of various disasters, and cannot judge the effect of disastrous weather, or give advice on the adoption of countermeasures when compiling decision-making service data or in the face of an impending meteorological disaster [2] [3] [4]. In order that decision-making service data can be more specific and practical, in this paper we did research into the spatial and temporal distribution characteristics of the rainstorm disaster occurring in Sichuan Province during 2002-2015, and investigated the possible causes of disaster formation based on the condition of the rainstorm disaster in Sichuan Province, in the hope of further developing a basic idea for the analysis of disastrous weather effects, to lay a solid foundation for the improvement of decision-making service efficiency and data compiling quality. Through the statistical analysis of relevant data, this paper has access to more serious areas of heavy rainstorms, to strengthen the monitoring of such areas, so as to make more accurate forecast of heavy rain, reducing the losses caused by rainstorms, and comprehensively protecting people's property.

\section{Data and Methodology}

\subsection{Selecting a Template}

The spatial and temporal distribution characteristics of rainstorm disaster in $\mathrm{Si}$ chuan Province were batted around by statistical analysis method based on 2002-2015 rainstorm disaster data of Sichuan Province (incomplete statistics performed according to the direct disaster reporting system).

\subsection{Maintaining the Integrity of the Specifications}

The template is used to format your paper and style the text. All margins, column widths, line spaces, and text fonts are prescribed; please do not alter them. You may note peculiarities. For example, the head margin in this template measures proportionately more than is customary. This measurement and others are deliberate, using specifications that anticipate your paper as one part of the entire journals, and not as an independent document. Please do not revise any of the current designations. 


\section{The Characteristics of Rainstorm Disaster in Sichuan Province}

\subsection{The Spatial Distribution Characteristics of Rainstorm Disaster}

The data of the storm disaster from 2002 to 2015 were obtained from the disaster reporting system in Sichuan Province, and the statistical analysis was carried out, so as to obtain the total number of rainstorms in Sichuan Province. See Figure 1. As can be seen in the frequency map (Figure 1) of rainstorm disaster in Sichuan Province, there are four major rainstorm disaster-prone regions in Sichuan Province, namely Dazhou and Bazhong in the northeastern basin, Mianyang and Ziyang in the northwestern basin, Ya'an, Meishan and Leshan in the southwestern basin, and the central Panzhihua-Xichang region. Rainstorm disaster occurred for 34 and 33 times respectively in Hongya and Tianquan in one of the disaster-prone regions, and 2 - 3 times averagely each year, while it frequently occurred in Miyi and Yanbian in the plateau area and Panzhihua-Xichang region, for 3 - 4 times averagely each year. Rainstorm disaster did not occur so frequently in Chengdu, Deyang and the sparsely-populated western Sichuan Plateau.

According to the comparison with the previous studies, the first three rainstorm disaster-prone regions have a good corresponding relationship with the three major rainstorm center regions in the basin area. In other words, the three major rainstorm center regions in the basin area are also the worst-hit areas.

\subsection{The Temporal Characteristics of Rainstorm Disaster}

\subsubsection{Earliest and Latest Date Analysis}

The analysis of the earliest and latest dates on which rainstorm disaster occurred in Sichuan Province during 2002-2015, as well as the occurrence locations, shows

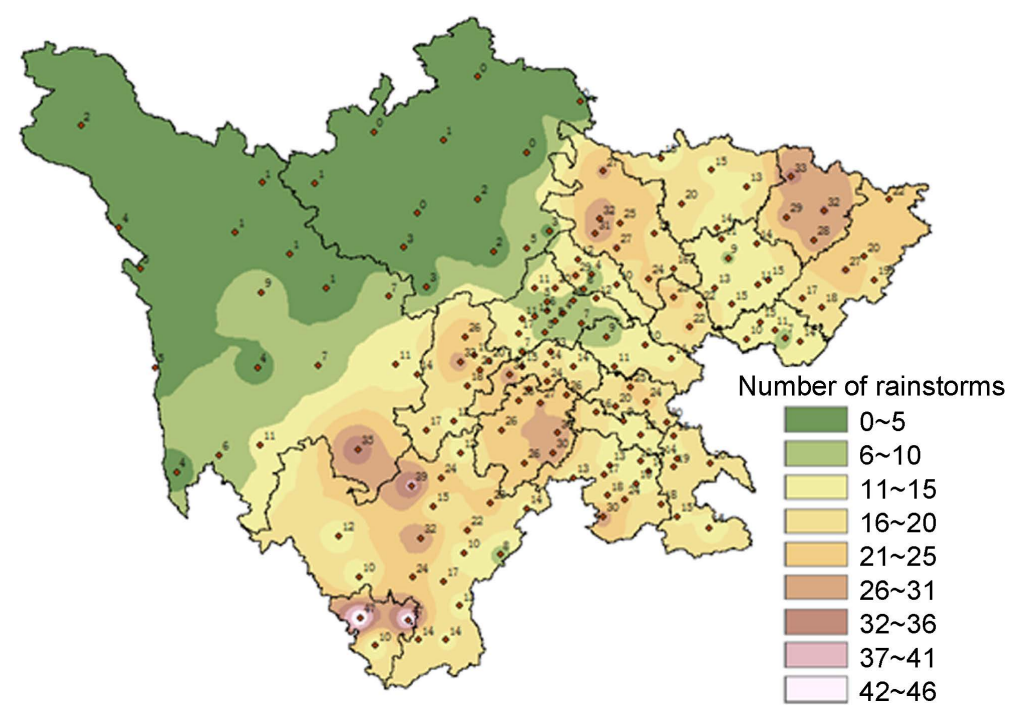

Figure 1. Distribution of total number of rainstorm disaster in Sichuan province in 2002-2015. 
that: 1) The first rainstorm disaster in the basin occurred on March 31, while the last one occurred on December 23; the earliest possible date on which rainstorm disaster occurred was in the middle of April or early May, while the most possible occurrence locations were Ya'an, Guang'an and Luzhou; the latest possible date on which rainstorm disaster occurred was in the middle and late September or early October, while the most possible occurrence locations were Guangyuan and Leshan; in the basin area, rainstorm disaster occurred earliest in the southern and northeastern basin, while latest in the southern and northwestern basin; 2) In the western Sichuan Plateau and Panzhihua-Xichang region, rainstorm disaster occurred earliest in the early May, and the most possible occurrence location was Meigu County, Liangshan Prefecture; the latest possible date on which rainstorm disaster occurred was in the late September, and the most possible occurrence locations were Miyi and Yanbian; the earliest and latest dates of occurrence were mainly concentrated in the eastern and southern Panzhihua-Xichang region, and the southeastern Ganzi Prefecture.

\subsubsection{Analysis of the Yearly and Monthly Occurrences}

As can be seen from the analysis of yearly and monthly disaster frequency in Sichuan Province (Figure 2): 1) in terms of interannual variation (Figure 2(a)), the rainstorm disaster frequency showed a fluctuation trend, and 2007 saw the highest frequency of disaster, while 2006 saw the lowest frequency. According to the wavelet analysis (Figure $2(\mathrm{~b})$ ), the frequency variation showed a significant

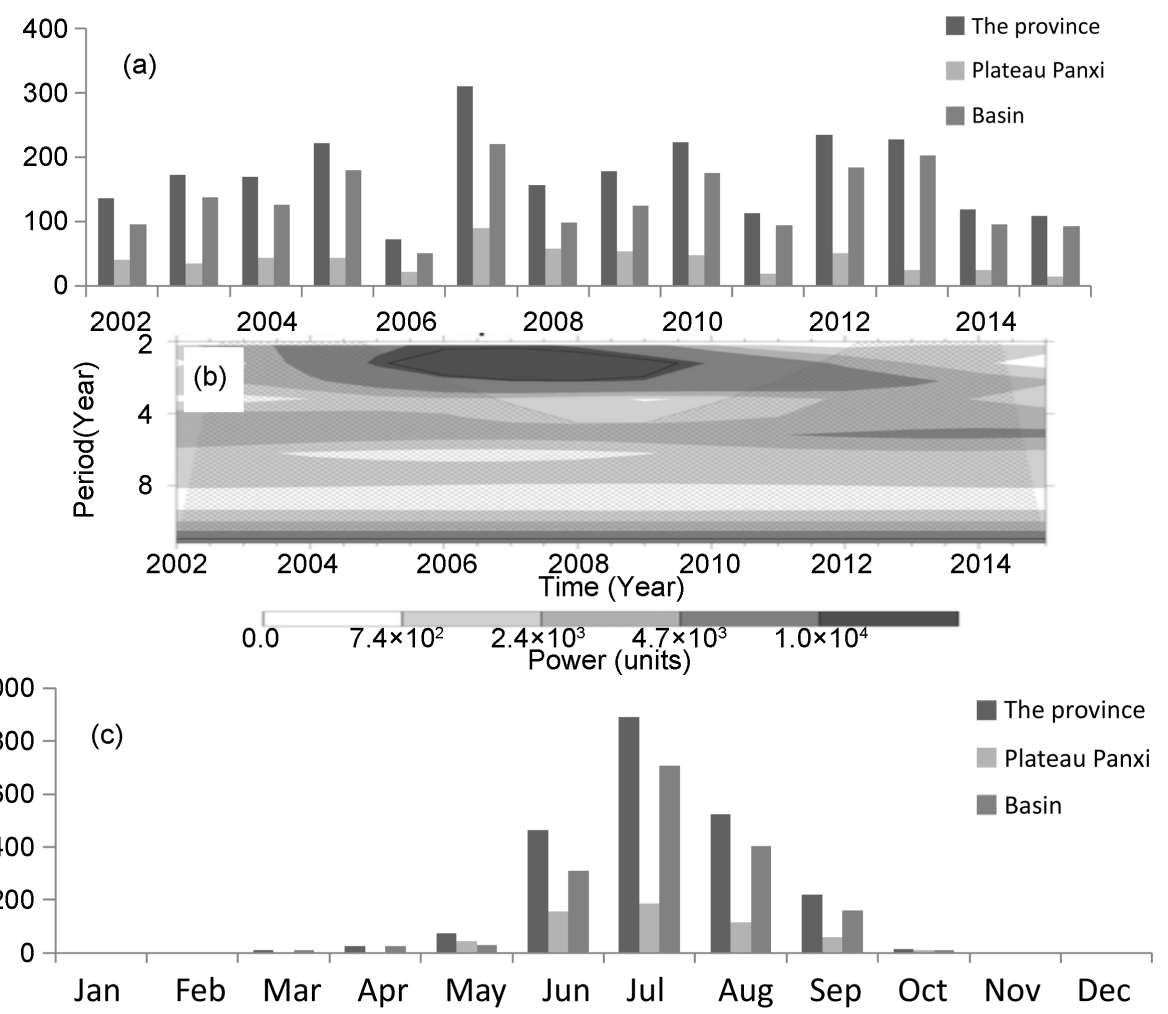

Figure 2. Yearly (a) and monthly (c) number of rainstorms and the number of years of changes in wavelet analysis (b). 
quasi-2-3-year oscillation period; 2) In terms of month (Figure 2(c)), rainstorm disaster occurred the most frequently throughout the province in July. It occurred for 893 times in all; it occurred for 708 times in the basin, and in 58 cities (counties) averagely each July; the main periods of occurrence were June, July and August, followed by May and September.

\subsubsection{Analysis of Monthly Regional Distribution}

According to the analysis of disaster distribution in June-September when rainstorm disaster occurred the most frequently in Sichuan Province (Figure 3), rainstorm disaster mainly occurred in the basin and Panzhihua-Xichang region, relatively less in the western Sichuan Plateau, and July saw the highest frequency of occurrence. The distribution of rainstorm disaster extended from the southern basin to the northwestward and finally to the northeastward in June-September. The disaster occurred relatively frequently in the northeastern and southern basin and Liangshan Prefecture in June, and among the several months, July saw the highest frequency of disaster occurrence, in which the disaster mainly occurred in the southwestern, northwestern and northeastern basin. The southwestern basin was still a primary occurrence area in August, and the
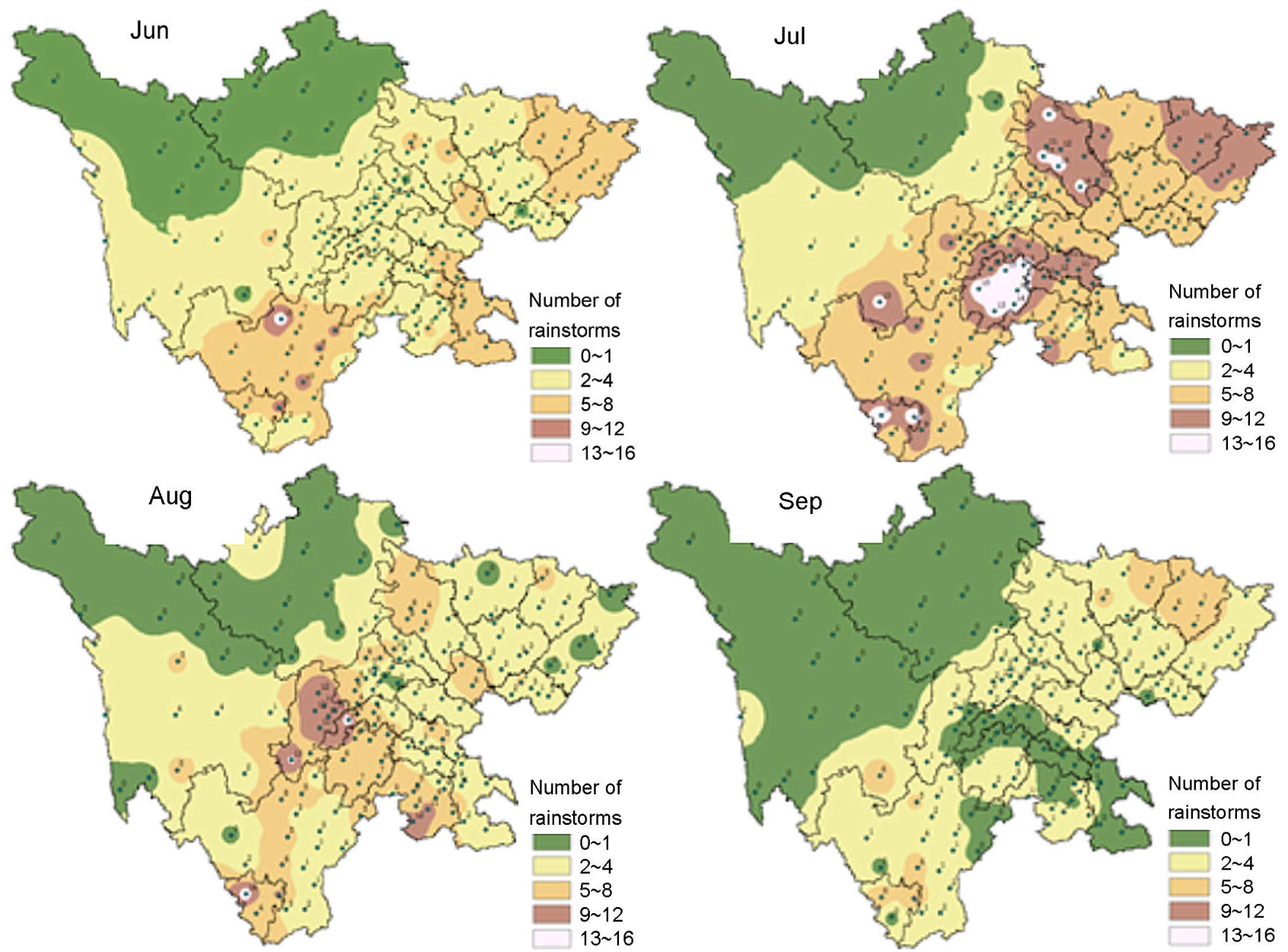

Figure 3. The geographical distribution of the number of disasters occurred in June-September. 
southern basin saw relatively low frequency of disaster occurrence in September, while the northeastern basin saw relatively high frequency of disaster occurrence.

As can be seen from the above analysis, rainstorm disaster occurred the most frequently in Ya'an, Meishan and Leshan in the southwestern basin. These regions saw $20 \%$ of the total rainfalls in the whole province, and rainstorm disaster mainly occurred in July and August.

\subsection{Analysis of Death in Disastrous Rainstorms}

\subsubsection{The Distribution of the Regions where People Died in Disastrous Rainstorms}

According to the National Bureau of disaster reduction statistics, we selected 143 cases of rainstorm disaster related to human death that occurred in Sichuan Province during 2002-2015, and made a statistic analysis of the death distribution in various regions (Figure 4), concluding that high death rate mainly existed in Bazhong, Dazhou and Panzhihua-Xichang region, while low rate in Neijiang and Meishan.

\subsubsection{Analysis of the Causes of Death in Disastrous Rainstorms}

69 cases containing well-preserved data of Sichuan Basin were selected for analysis (Table 1). 77\% of the disastrous rainstorms started to fall at 8:00 p.m. - 5:00 a.m. According to the separate analysis of each part of the basin, the rainstorms resulting in death in the northwestern basin (Guangyuan, Mianyang, Deyang and Chengdu) lasted roughly 3 days (d), the maximum hourly rainfall (During a certain period of time, the depth of rain that falls to a level of ground (assuming no leakage, evaporation, loss, etc.) is called rainfall. The maximum hourly rainfall is the maximum amount of total rainfall that falls on an area within 1 hour.) reached $60-80 \mathrm{~mm}$, and the maximum daily rainfall reached $200-300 \mathrm{~mm}$. The major cause of rainstorm was torrential flooding, followed by debris flow (Debris flow refers to the mountainous or other valleys of deep valleys, terrain in steep areas, because of heavy rain, Blizzard or other natural disasters caused by

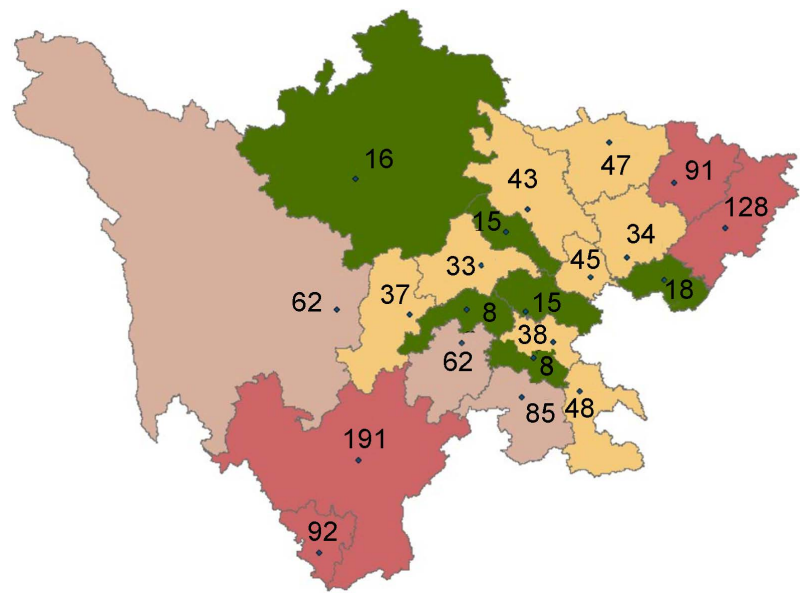

Figure 4. The distribution of the death toll in the rainstorm. 
Table 1. Torrential rain disasters in 2002-2015 deaths more cases.

\begin{tabular}{|c|c|c|c|c|c|c|c|}
\hline Basin & Location & Time & $\begin{array}{c}\text { The number } \\
\text { of people }\end{array}$ & ${ }^{\mathrm{r}}$ Continued & $\begin{array}{c}\text { Maximum } \\
\text { hourly rainfall }\end{array}$ & $\begin{array}{l}\text { Maximum daily } \\
\text { rainfall }\end{array}$ & Reason \\
\hline \multirow{3}{*}{ North-west } & Guangyuan & Jul. 2010 & 15 & 4 days & $67.1 \mathrm{~mm}$ & $310.3 \mathrm{~mm}$ & $\begin{array}{l}\text { Flash } \\
\text { floods }\end{array}$ \\
\hline & t Mianyang & Sep. 2008 & 14 & 3 days & $66.1 \mathrm{~mm}$ & $351.3 \mathrm{~mm}$ & $\begin{array}{l}\text { Flash } \\
\text { floods }\end{array}$ \\
\hline & Mianzhu & Aug. 2010 & 9 & 2 days & $37.4 \mathrm{~mm}$ & $227.5 \mathrm{~mm}$ & $\begin{array}{l}\text { Debris } \\
\text { flow }\end{array}$ \\
\hline \multirow[b]{2}{*}{ South-west } & Tianquan & Jun. 2012 & 3 & 2 days & $14.1 \mathrm{~mm}$ & $60.1 \mathrm{~mm}$ & Landslide \\
\hline & Yingjing & Aug. 2012 & 2 & 2 days & $23.6 \mathrm{~mm}$ & $62.2 \mathrm{~mm}$ & $\begin{array}{l}\text { Debris } \\
\text { flow }\end{array}$ \\
\hline \multirow{2}{*}{ Central } & Suining & Sep. 2012 & 13 & 2 days & $129 \mathrm{~mm}$ & $333 \mathrm{~mm}$ & Flood \\
\hline & Suining & Jun. 2013 & 7 & 3 days & $153.9 \mathrm{~mm}$ & $385.8 \mathrm{~mm}$ & Flood \\
\hline \multirow{3}{*}{ North-east } & Dazhou & Jul. 2009 & 5 & 4 days & $59.9 \mathrm{~mm}$ & $226.7 \mathrm{~mm}$ & Flood \\
\hline & Bazhong & Sep. 2011 & 21 & 4 days & $59.5 \mathrm{~mm}$ & $317.5 \mathrm{~mm}$ & Landslide \\
\hline & Bazhong & Jul. 2010 & 9 & 3 days & $74.5 \mathrm{~mm}$ & $337.5 \mathrm{~mm}$ & Flood \\
\hline \multirow{2}{*}{ South } & Yibin & Jun. 2012 & 5 & 2 days & $35.9 \mathrm{~mm}$ & $92.3 \mathrm{~mm}$ & Landslide \\
\hline & Yibin & Jun. 2011 & 4 & 2 days & $44.3 \mathrm{~mm}$ & $104.6 \mathrm{~mm}$ & Landslide \\
\hline
\end{tabular}

landslides and carrying a large number of sediment and stones of the special torrent. Debris flow has a sudden and fast flow, flow, material capacity and destructive power and so on. The main danger of debris flow is the destruction of towns, enterprises and institutions, factories, mines, villages, causing casualties, destruction of houses and other engineering facilities, destruction of crops, trees and arable land. In addition, debris flows sometimes block the river, not only to block shipping, but also may cause floods), and rainstorm contributed to high death tolls in the northwestern basin, as well as Qingchuan, Wangcang and Mianzhu; rainstorm almost lasted 2d in the southwestern basin (Ya'an, Meishan and Leshan), but the maximum duration was $8 \mathrm{~d}$, the maximum hourly rainfall ranged from $14.1 \mathrm{~mm}$ to $142 \mathrm{~mm}$, and the maximum daily rainfall reached 200 $\mathrm{mm}$ or so. The major cause of rainstorm was landslide, and rainstorm contributed to high death tolls in the southwestern basin including Tianquan, Yingjing and Hongya; rainstorm almost lasted 2 - 3d in the central basin (Suining, Ziyang and Neijiang), the maximum hourly rainfall was not less than $80 \mathrm{~mm}$, and the maximum daily rainfall ranged from $200 \mathrm{~mm}$ to $250 \mathrm{~mm}$. The major causes of rainstorm were torrential flooding and landslide, and rainstorm contributed to high death tolls in Suining and Neijiang; rainstorm lasted 3d or so in the northeastern basin (Bazhong, Dazhou, Nanchong and Guang'an), the maximum hourly rainfall reached $50-70 \mathrm{~mm}$, and the maximum daily rainfall reached 200 $300 \mathrm{~mm}$. The major causes of rainstorm were flooding and house collapse, and rainstorm contributed to high death tolls in Bazhong and Dazhou; rainstorm almost lasted $2 \mathrm{~d}$ in the southern basin (Zigong, Luzhou and Yibin), the maximum hourly rainfall ranged from roughly $30 \mathrm{~mm}$ to $80-90 \mathrm{~mm}$, and the maximum daily rainfall almost reached $100 \mathrm{~mm}$. The major cause of disaster was 
landslide, and rainstorm contributed to high death tolls in Gao County, Gong County and Gulin County. According to the analysis of the rainstorm disaster data, there is some difference between the magnitude of disastrous rainstorm in different parts of the basin and the major causes of disaster. For instance, due to frequent rains in the mountain areas in the southwestern basin throughout the year, geological disasters are easily caused even if the maximum hourly rainfall and maximum daily rainfall are relatively low; frequent geological disasters lead to human death in the southwestern and southern basin, while flood often occurs in the northwestern and central basin; second, rainstorm bursts out relatively frequently at night, and this is not conducive to transferring residents; in addition, the disaster contributes to high death tolls in both basin and mountain areas, but the analysis shows that most people died around the mountain areas and rivers. Especially, disasters are caused more easily in Sichuan Province where there are complicated terrains, as well as many mountain areas and rivers; finally, lots of disaster events also reflect that the residents in some regions have weak awareness of disaster prevention, and lack the experience and general knowledge of disaster prevention [5] [6] [7]. Moreover, the departments concerned cannot adopt perfect emergency measures, but respond to disasters sluggishly. All these are important causes of casualties in rainstorm disaster, which are worth pondering and discussing for meteorologists.

\section{Conclusions and Discussion}

This paper detailed the spatial and temporal distribution characteristics of rainstorm disaster in Sichuan Province by statistical analysis method based on relevant cases of rainstorm and 2002-2015 rainstorm disaster data of Sichuan Province, coming to the following main conclusions:

1) Rainstorm disaster is distributed mainly in the northeastern Sichuan Basin including Dazhou and Bazhong, the northwestern basin including Mianyang and Ziyang, the southwestern basin including Ya'an, Meishan and Leshan, and the central Panzhihua-Xichang region. These regions have a corresponding relationship with the rainstorm center regions in Sichuan Province.

2) The variation of rainstorm disaster frequency in Sichuan Province is subject to a significant quasi-2-3-year oscillation period. In terms of month, June, July and August see the heaviest rainstorms.

3) According to the analysis of the cases related to human death, there are some differences between the magnitude of disastrous rainstorm in the five parts of the basin and the major causes of disaster, and flooding is the major cause in the northwestern and central basin; landslide and debris flow are the major causes of disaster in the southwestern and southern basin, particularly disasters may also be caused in the southwestern basin even if the maximum hourly rainfall and maximum daily rainfall are relatively low; disasters may be caused easily in the northeastern basin given long rainfall duration and great rainfall.

The occurrence of heavy rain is mainly affected by atmospheric circulation and weather, climate system, is a natural phenomenon. However the rain on the 
social production and life is a disaster, which depends on the socio-economic, population, disaster prevention and disaster resistance and many other factors. Thus the occurrence of rainstorms is not only because of a natural reason, but also its social and human factors. Grasping the temporal and spatial distribution of rainstorm characteristics, for disaster prevention and mitigation is of great significance.

\section{References}

[1] Wen, K.G., Li, H. and Zhan, Z.Y. (2006) China Meteorological Disaster Ceremony in Sichuan. Chinese Meteorological Press, Beijing.

[2] Ma, L., Feng, H.Z. and Yang, J. (2014) Sichuan Weather Forecast Manual. Southwest Jiaotong University Press, Chengdu.

[3] Zhang, J.Z., Sun, J., Zhang, L.S. and Yang, K. (2013) Local Natural Disasters, Natural and Social Needs and Service Needs. National Decision Meteorological Service Business Technology Seminar (2013) Excellent Papers Compilation, 48-54.

[4] Han, X.J. and Sun, X.W. (2013) Discussion on the Index and Influence Analysis of Disastrous Weather Service. National Decision Meteorological Service Business Technology Seminar (2013) Excellent Papers Compilation, 102-108.

[5] Min, F.H., Liu, T.T. and Li, J. (2013) Analysis of Chongqing Meteorological Disasters. National Decision Meteorological Service Business Technology Seminar (2013) Excellent Papers Compilation, 350-354.

[6] Bulletin on the Comprehensive Promotion of Heavy Rain Caused by Small and Medium River Floods and Flash Floods Geological Hazards of Weather Warning Service Operational Notice. (2013) Disaster Reduction Letter No.201342.

[7] Gao, Y.Z., Xing, J.J. and Wang, C.L. (2006) Causes and Forecasting Methods of Heavy Rainfall. Journal of Natural Disasters, 15, 65-70.

\section{Submit or recommend next manuscript to SCIRP and we will provide best service for you:}

Accepting pre-submission inquiries through Email, Facebook, LinkedIn, Twitter, etc. A wide selection of journals (inclusive of 9 subjects, more than 200 journals)

Providing 24-hour high-quality service

User-friendly online submission system

Fair and swift peer-review system

Efficient typesetting and proofreading procedure

Display of the result of downloads and visits, as well as the number of cited articles

Maximum dissemination of your research work

Submit your manuscript at: http://papersubmission.scirp.org/

Or contact gep@scirp.org 